удк 338.432

DOI: https://doi.org/10.32851/2708-0366/2020.3.7

Боровік Л.В.

доктор економічних наук, доцент, доцент кафедри економіки та фрінансів,

Херсонський державний аграрно-економічний університет ORCID: https://orcid.org/0000-0001-7200-0497

\author{
Borovik Liubov
}

Kherson State Agrarian and Economic University

\title{
СТРАТЕГІЯ УПРАВЛІННЯ КОНКУРЕНТОСПРОМОЖНІСТЮ АГРАРНИХ ПІДПРИЄМСТВ
}

\section{STRATEGY OF COMPETITIVENESS MANAGEMENT OF AGRICULTURAL ENTERPRISES}

Управління конкурентоспроможністю аграрних підприємств є надзвичайно складним завданням, оскільки їхня господарська діяльність перебуває під впливом багатьох чинників, які діють за певних умов із різною інтенсивністю і характеризуються багатовекторністю. Найважливішими чинниками конкурентних переваг аграрних підприємств у регіоні $\epsilon$ : ресурсний потенціал; фінансове становище; кон'юнктура на ринку сільськогосподарської продукиії; інноваційно-інвестиційний, технічний, технологічний, інфраструктурний, кадровий та соиіальний потенціал. Організаційно-економічний механізм підвищення конкурентоспроможності аграрних підприємств повинен включати такі заходи державної підтримки: науково-технічну та інноваційно-технологічну політику; інвестиційну, цінову, податкову, фінансово-кредитну, зовнішньоекономічну, антимонопольну, антикримінногену, антикорупційну політику. Держава повинна на законодавчому рівні підтримувати розвиток інтеграційних процесів, сприяти відновленню зрошуваної та дренажної систем у регіоні, здійснювати контроль над використанням земельних і водних ресурсів.

Ключові слова: стратегія, конкурентоспроможність, аграрне підприємство.

Управление конкурентоспособностью аграрных предприятий является чрезвычайно сложной задачей, поскольку их хозяйственная деятельность находится под влиянием многих факторов, которые действуют при определенных условиях с разной интенсивностью и характеризуются многовекторностью. Важнейшими факторами конкурентных преимущзеств аграрных предприятий в регионе являются: ресурсный потенцииал; финансовое положение; конъюнктура на рынке сельскохозяйственной продукции; инновационно-инвестиционный, технический, технологический, инфраструктурный, кадровый и социальный потенциал. Организационно-экономический механизм повынения конкурентоспособности аграрных предприятий должен включать следующче меры государственной поддержки: научно-техническю и инновационно-технологическую политику; инвестиционную, иеновую, налоговую, финансово-кредитную, внешнеэкономическую, антимонопольную, антикриминогенную, антикоррупциионую политику. Государство должно на законодательном уровне поддерживать развитие интеграционных процессов, содействовать восстановлению орошаемой и дренажной систем в регионе, осуществлять контроль над использованием земельных и водных ресурсов.

Ключевые слова: стратегия, конкурентоспособность, аграрное предприятие.

The management of the competitiveness of agricultural enterprises is an extremely difficult task, since their economic activity is influenced by many factors that act under certain conditions with different intensity and are characterized by a multi-vector nature. The most important factors in the competitive advantages of agricultural enterprises in the region are resource potential; financial position; market conditions for agricultural products; innovation and investment, technical, technological, infrastructural, human and social potential. The organizational and economic mechanism for increasing the competitiveness of agricultural enterprises should include the following measures of state support: scientific-technical and innovation-technological policy; 
investment, price, tax, financial and credit, foreign economic, antimonopoly, anti-crime, anticorruption policy. The state should at the legislative level support the development of integration processes, promote the restoration of irrigated and drainage systems in the region; exercise control over the use of land and water resources. The components of state regulation of the development of the agricultural sphere of production should be: the adoption of state and regional programs to create favorable conditions for the development of agricultural production; cheaper loans; increasing the solvency of the population; creation of an effective system of quality control of raw materials and finished products in accordance with international standards; promoting the introduction of innovative technologies in the production and processing of agricultural raw materials. Endogenous factors of scientific and technical improvement of production processes are of great importance in achieving competitive advantages; training of highly qualified personnel for agricultural enterprises; improving the management system of production processes, finance, marketing; effective management of investment resources; equity and debt management; working capital management. The experience of developed countries shows that one of the ways to improve the competitive advantages of agricultural enterprises is cooperation, the creation of integration structures with a common production infrastructure.

Key words: strategy, competitiveness, agricultural enterprise.

Постановка проблеми. Розробляючи стратегію підвищення конкурентоспроможності продукції, необхідно активізувати пошук зовнішніх джерел інвестування виробництва, оскільки можливості самофінансування господарської діяльності сільськогосподарських підприємств практично вичерпані.

Аналіз останніх досліджень і публікацій. Питанням визначення чинників впливу на зміцнення конкурентних позицій сучасних агропромислових підприємств присвячено дослідження таких вітчизняних і зарубіжних економістів, як А.Н. Бланк, О.М. Бородіна, Ю.В. Масюк, П.Т. Саблук, Р.А. Фатхутдінов, В.Т. Федоренко, В.Г. Чабан та ін.

Формулювання цілей статті. Незважаючи на велику кількість наукових праць, присвячених конкурентоспроможності аграрних підприємств, усе ще не розкрита проблема підвищення конкурентних переваг шляхом упровадження інновацій, зміцнення сировинної бази переробних підприємств, удосконалення взаємин між сільськогосподарськими і переробними підприємствами, впровадження маркетингових досліджень та ін.

Виклад основного матеріалу. Багаторазово вченими робилися і робляться спроби систематизації різних чинників впливу на формування конкурентного середовища. До чинників впливу на конкурентні переваги підприємств вони відносять економічні, політичні, правові, технологічні, природні, географічні, соціальні, міжнародні, регіональні, стратегічні та ін.

Ураховуючи напрацювання вказаних вище авторів, а також особливості економічного і соціального розвитку Херсонської області, ми класифікували чинники впливу на конкурентоспроможність аграрних підприємств (рис. 1, 2).

Під чинниками впливу на формування конкурентних переваг сільськогосподарських підприємств треба розуміти умови здійснення господарських процесів і причини, що впливають на ці процеси. Вони взаємозалежні, характеризуються багатовекторністю, а отже, впливають на економічну діяльність підприємства як позитивно, так і негативно.

До системи заходів державної підтримки вітчизняного виробника сільськогосподарської продукції слід віднеси пільгове оподаткування та кредитування, бюджетне фінансування програм розвитку сільського господарства та соціальної і ринкової інфраструктури в сільській місцевості.

Складниками державного регулювання розвитку сільськогосподарської сфери виробництва мають бути: прийняття державної і регіональної програм створення сприятливих умов розвитку сільськогосподарського виробництва; здешевлення кредитів; підвищення платоспроможності населення; створення ефективної системи контролю над якістю сировини та готової продукції відповідно до міжнародних стан- 
Екзогенні чинники

\begin{tabular}{|l|l|}
\hline Вплив & - система заходів державної підтримки виробника \\
органів влади & сільськогосподарської продукції; \\
& - науково-технічна та інноваційно-технологічна політика; \\
& - цінова політика; \\
& - податкова політика; \\
& - антикорупційна політика; \\
& - зовикриміногенна політика; \\
& - фінансово-кредитна політика; \\
& - державна стандартизація якості продукції; \\
& - антимонопольна політика; \\
& - підтримка розвитку інтеграційних процесів; \\
& - відновлення зрошуваної та дренажної систем; \\
& - контроль над використанням земельних і водних ресурсів. \\
\hline Вплив ринку & Розвиток конкуренції на ринку \\
& Розвиток міжгалузевих зв’язків \\
& Зміна кон’юнктури на ринку \\
& Природно-кліматичні чинники \\
& Зміна соціально-економічної ситуації \\
& Розвиток ринкової інфраструктури \\
\hline
\end{tabular}

Рис. 1. Класифікація екзогенних чинників впливу на формування конкурентних переваг сільськогосподарських підприємств у Херсонській області

\begin{tabular}{|l|l|}
\hline \multicolumn{1}{l|}{} & \multicolumn{1}{|c|}{ Ендогенні чинники } \\
\hline $\begin{array}{l}\text { Внутрішньо- } \\
\text { господарські } \\
\text { чинники } \\
\text { впливу }\end{array}$ & $\begin{array}{l}\text { Ннявність висококваліфікованих працівників } \\
\text { Рівень забезпечення технічними засобами } \\
\text { Наяність зрошуваних земель сільськогосподарського } \\
\text { призначення } \\
\text { Організаційна структура підприємства } \\
\text { Організація системи управління } \\
\text { Форма власності на основні засоби виробництва } \\
\text { Фінансове становище } \\
\text { Маркетингова діяльність } \\
\text { Розвиток соціальної інфраструктури }\end{array}$ \\
\hline
\end{tabular}

Рис. 2. Класифікація ендогенних чинників впливу на формування конкурентних переваг сільськогосподарських підприємств у Херсонській області 
дартів; сприяння впровадженню інноваційних технологій у виробництво і переробку сільськогосподарської сировини.

У досягненні конкурентних переваг велике значення мають ендогенні чинники: науково-технічне вдосконалення процесів виробництва; підготовка висококваліфікованих кадрів для сільгосппідприємств; удосконалення системи управління виробничими процесами, фінансами, маркетингом; ефективне управління інвестиційними ресурсами; управління власним і позиковим капіталом; управління обіговим капіталом та ін.

Система управління обіговим капіталом є важливою частиною забезпечення ефективної діяльності сільськогосподарського підприємства та його конкурентоспроможності. Сутність і теорія управління обіговим капіталом достатньо висвітлена у наукових працях як вітчизняних, так і зарубіжних учених-економістів: Л. Аврамчука [1], А. Бланка [2], В. Ковальова [3], Л. Павлової [4], Ю. Лупенко [5] та ін.

Забезпечення сільськогосподарського підприємства обіговим капіталом впливає на його конкурентоспроможність, оскільки він:

- відіграє головну роль у забезпеченні платоспроможності підприємства;

- генерує певний прибуток під час його використання у виробничо-збутовій діяльності;

- охоплює велику кількість запасів, товарно-матеріальних цінностей, грошові кошти та високоліквідні цінні папери.

До основних причин зниження конкурентних переваг сільськогосподарських підприємств слід віднести:

- майже повну відсутність державних замовлень на всі види сільськогосподарської продукції і сировини;

- скорочення зрошуваних земель у регіоні;

- розрив виробничих зв'язків між переробними і сільськогосподарськими підприємствами;

- нестача обігових коштів для виробництва якісної та дешевої продукції у сільгоспвиробників і закупівлі переробниками вирощеної сировини;

- відсутність дієвого захисту внутрішнього ринку від надмірного завезення сільськогосподарських продуктів харчування із зарубіжних країн та інших регіонів;

- д диспаритет цін між сільськогосподарською і промисловою продукцією;

- висока ціна на енергоносії;

- недосконала система оподаткування та банківсько-фінансової політики;

- відсутність ефективної підтримки виробників сільськогосподарської продукції з боку держави;

- фізичний і моральний знос агровиробничих засобів;

- відсутність коштів на впровадження інноваційних технологій;

- монополізм переробних і торгових підприємств;

- тіньовий метод закупівлі продукції у сільгоспвиробників;

- низька купівельна спроможність населення;

- недостатнє інвестування сільськогосподарської сфери виробництва.

Досвід розвинених країн показує, що одним зі шляхів поліпшення конкурентних переваг сільськогосподарських підприємств $є$ кооперація, створення інтеграційних структур зі спільною виробничою інфраструктурою.

Сільськогосподарські підприємства, які є учасниками внутрішньогалузевих або ж міжгалузевих об’єднань, мають значні конкурентні переваги, а саме: постійно залучаються до виконання інвестиційно-інноваційних регіональних і державних програм, у ході реалізації яких відбувається реальна фінансова підтримка сільгоспвиробників; співпрацюють із науковими установами в плані реалізації сучасних технологій; в умовах кризи неплатежів проводять взаємозаліки, значно не зменшуючи обсяг обіго- 
вих коштів; ефективно співпрацюють із кредитними та інвестиційними установами; маючи єдину для всіх учасників об'єднання цінову політику та маркетингову службу, мають можливість постійно забезпечувати своє економічне зростання; єдина служба постачання дає можливість значного зниження витрат на придбання матеріалів за допомогою оптових закупівель; формування значних партій сільськогосподарської продукції і сировини дає можливість підтримувати сталі зв'язки з торговельними структурами на міжрегіональному і міждержавному рівнях.

Головною умовою сталого економічного розвитку інтегрованих структур є підвищення конкурентоспроможності продукції, яку виробляють підприємства об'єднання.

Стратегія підвищення конкурентоспроможності продукції повинна враховувати високий рівень нестабільності зовнішнього середовища, нерозвиненість інформаційної інфраструктури, незадовільний організаційний і технологічний рівень виробництва, дефіцит фінансових ресурсів та платоспроможного попиту на внутрішньому ринку і низьку конкурентоспроможність продукції на зовнішньому ринку, легальний і нелегальний увіз продуктів харчування сільськогосподарського походження 3-за кордону. Постійна зміна державою правил експортно-імпортних відносин негативно позначається на результатах економічної діяльності господарств і ускладнює процес формування стратегії підвищення конкурентоспроможності вітчизняної продукції.

Недосконалість законодавства перешкоджає проведенню об'єктивного аналізу зовнішнього конкурентного середовища та обгрунтованому прогнозуванню перспектив розвитку підприємств. Створення інформаційної інфраструктури сприятиме вирішенню цієї проблеми. При цьому основним елементом зовнішньої інформаційної структури має бути база даних, яка формується галузевими спілками підприємств, Державним комітетом статистики, Антимонопольним комітетом, Державним інформаційно-аналітичним центром моніторингу ринків, консалтинговими фірмами і інформаційними агенціями. Вони повинні містити інформацію про рівень конкуренції на ринках виробництва сировини і збуту готової продукції та перспективи виходу на нові як внутрішні, так і зовнішні ринки. Така база даних сьогодні не має вільного доступу для товаровиробників, що сповільнює розвиток ринків збуту і вільної конкуренції.

Внутрішня інформаційна інфраструктура повинна складатися з внутрішньовиробничої звітності і давати інформацію про зміни у зовнішньому середовищі, корисну для корегування діючої на підприємстві стратегії підвищення конкурентоспроможності продукції.

Невідповідність рівня технічного оснащення сільськогосподарських підприємств та зстаріли методи управління ними є вагомими причинами низької конкурентоспроможності сільськогосподарської продукції в регіоні. Сільськогосподарська машинобудівна галузь в Україні знаходиться в занепаді, а Херсонський машинобудівний завод - у кризовому стані; в останні роки він не випускає сучасні дощувальні машини для зрошуваного землеробства, а зернові комбайни його виробництва не відповідають світовим зразкам і не задовольняють запити сільгоспвиробників. Маючи великі перспективи зростання виробництва овочевої продукції в регіоні, не йдеться і про налагодження випуску овочезбиральної техніки.

Використання застарілої техніки на полях та несучасного обладнання на переробних підприємствах області призводить до зниження якості готової продукції та підвищення іiі собівартості, що знижує іiї конкурентні переваги.

Вирішити проблему зростання обсягів виробництва сільськогосподарської сировини та якісної іï переробки на відповідних підприємствах можливо лише шляхом пожвавлення інвестиційної та інноваційної діяльності структурної й організаційної перебудови управління підприємствами. У найширшому розумінні агроінновація - це нововведення, що реалізується в аграрній сфері. Науковці пропонують різні підходи до визначення цього поняття. Так, агроінновацію трактують як системні впровадження в 
аграрну сферу результатів науково-дослідної роботи й як результат праці, отриманий завдяки застосуванню нових наукових знань [6].

Фінансувати із власних коштів інвестиційні проєкти (закупівлю техніки, добрив, пестицидів, племінних тварин та ін.) реально під силу лише невеликій частині сільгосппідприємств. Внутрішнє інвестування в аграрному секторі регіону необхідно розглядати як теоретично можливу форму фінансування інвестиційних проєктів i програм.

Залучення зовнішнього інвестування повинно розглядатися як об’єктивна передумова нарощування власного капіталу. Під час дослідження можливостей залучення зовнішніх ресурсів інвестування стосовно умов аграрного сектору економіки як пріоритетні напрями доцільно розглянути: емісію цінних паперів; нарощування централізованих інвестицій; активізацію приватних інвесторів (населення, комерційних банків, інвестиційних фондів і компаній та ін.); залучення іноземних інвестицій.

Важливою формою зовнішнього інвестування інвестиційних проєктів є отримання фінансових ресурсів шляхом випуску акцій. Акціонерний капітал може вноситися у формі грошових внесків, устаткування, технологій, прав користування національними ресурсами (якщо акціонером є держава). Привабливість даної форми фінансування полягає у тому, що основна сума фінансових та інших ресурсів надходить на підприємство на початку реалізації проєкту, а виплату дивідендів можна перенести на більш пізні терміни, коли зросте можливість проєкту генерувати доходи.

Інвестування проєкту за рахунок емісії акцій припускає, що підприємство, що здійснює фінансування, організоване як відкрите акційне товариство, якщо йдеться про продаж цінних паперів «новим акціонерам».

Значення такого джерела зовнішнього інвестування, як банківські кредити, в Україні значно нижче, ніж у розвинених країнах Заходу. Вітчизняні комерційні банки надають своїм клієнтам переважно короткострокові кредити під закупівлю оборотних засобів, а не під довгострокові інвестиційні проєкти. Це пов'язано з тим, що комерційне кредитування сільгосппідприємств є більш ризикованим, аніж кредитування підприємств інших галузей економіки, оскільки у даній сфері діяльності існує низка непідконтрольних чинників впливу на результати виробничої діяльності, а саме природно-кліматичні та погодні умови. Це зумовлює вищі відсоткові ставки для аграрних підприємств порівняно з промисловими і торговими.

Довгострокове інвестування може здійснюватися не лише за рахунок кредитів, отриманих підприємством у комерційному банку. Інвестором може виступати держава, яка здійснює фінансування агропромислового виробництва за рахунок засобів державного бюджету, місцевих бюджетів і позабюджетних фондів. Активізація державної участі в інвестиційній діяльності є одним із найважливіших чинників підвищення конкурентоспроможності сільськогосподарської продукції. Особливо важливими у цьому плані є державні централізовані інвестиції, які отримують учасники виконання цільових державних програм.

Стратегія підвищення конкурентоспроможності продукції повинна врахувати такий чинник інвестування виробництва сільськогосподарської продукції, як іпотека, котра $є$ важливим джерелом довгострокового інвестування. В останні роки зріс інтерес до іпотеки в сільськогосподарській сфері виробництва у зв'язку з реформуванням земельних відносин. Але при цьому треба пам'ятати, що земельні фонди сільськогосподарського призначення є власністю селян, а не великих чи малих сільгосппідприємств. Тому кооперування одноосібних селянських господарств дасть їм змогу здавати в заставу значні земельні масиви, закуповувати сучасну техніку, необхідну для ведення виробництва. При цьому зросте ііі потреба конкурувати з великими підприємствами на ринках збуту продукції. Здорова конкуренція між товаровиробниками в межах сільськогосподарської галузі регіону неодмінно стане основою структурної 
перебудови великих господарств, призведе до інтеграційних процесів в АПК регіону, що поліпшить конкурентні позиції товаровиробників на зовнішньому ринку.

Одним із важливих чинників регіонального інвестування сільгосппідприємств $є$ кредитні спілки та заощадження населення.

Кредитні спілки - це кооперативні організації, що створюються з метою акумуляції заощаджень своїх членів та їх взаємного кредитування. Ініціаторами їх утворення можуть виступати підприємства та їхні інтегровані об'єднання, профспілки, церковні громади, місцеві органи самоврядування [7]. Спільність інтересів осіб, що формують кредитну спілку, визначається потребами у дохідному розміщенні власних коштів та можливістю оперативного отримання кредиту на власні потреби.

Не залучені у позичкові операції кошти кредитні спілки можуть депонувати на окремих рахунках у комерційних банках або ж інвестувати їх у короткострокові державні боргові зобов'язання.

Маючи статус некомерційних громадських організацій та пільги в оподаткуванні, кредитні спілки спроможні забезпечувати вищий рівень дохідності за внесками своїх членів та стягувати з них нижчі проценти за позики, ніж комерційні банки.

Здійснюючи свою діяльність, кредитні спілки кредитують не лише окремі аграрні підприємства регіону, а й інфраструктури, що займаються заготівлею, переробкою, зберіганням та збором сільськогосподарської продукції.

У Херсонській області діють понад 30 кредитних спілок, чотири з яких найбільш активно співпрацюють із фермерськими та одноосібними сільськими господарствами. Тільки за один рік кредитна спілка «Громада» надає понад 2 тис сільгосппідприємств кредитів на суму близько 37 млн грн.

Фізичні особи - отримувачі високих доходів концентрують основну масу заощаджень для спрямування своїх накопичених коштів, як правило, не в реальний сектор економіки, що характеризується високим ризиком кредитування, а у сферу обігу (посередницькі, валютні, зовнішньо- та внутрішньоторговельні операції тощо). Зі збільшенням обсягів заощаджень вони мають реальну можливість переводити заощадження у реальні виробничі інвестиції, створюючи вагомий інвестиційний ресурс регіону.

Особливого значення серед чинників загальної стратегії підвищення конкурентоспроможності продукції у Херсонській області набуває інвестування сільськогосподарських і переробних підприємств іноземними компаніями. До п’ятірки найбільших країн-інвесторів входять Сполучене Королівство, Греція, Кіпр, Російська Федерація та Ліберія.

Із такими країнами, як Німеччина, США, Канада, Угорщина, Ліхтенштейн, аграрні підприємства Херсонщини мають налагоджені довготривалі економічні зв'язки. Насамперед іноземні компанії вкладають кошти в овочівницьку галузь. Прикладом удалого інвестування в розвиток цієї галузі може бути спільна діяльність україно-шведського підприємства «Чумак», україно-американського «Фрідом Фарм» та ін. [7].

Стратегія підвищення конкурентоспроможності сільгосппродукції повинна передбачати зміцнення своїх позицій на міжнародному рівні.

Починаючи з 2000 р. ділова активність сільгосппідприємств та закупівельноторгових структур у регіоні постійно зростає. Обсяг експортних операцій значно перевищує імпортні. Найбільші обсяги в експорті мають такі країни, як Росія, Туреччина, Німеччина, Угорщина.

Традиційними експортними товарами Херсонщини є зернові, насіння і плоди олійних культур, жири та олія, готові до споживання продукти тваринного і рослинного походження.

Експорт товарів та послуг до країн ЄС становить 32,8\% до загального обігу експорту області, до країн СНД - 33,1\%, імпорт відповідно становить 28,6\% та 24,7\%. 
Обсяги зовнішньої торгівлі товарами з країнами СНД та ЄС свідчать про тенденцію зростання обсягів експорту продукції сільського господарства. Очікуване збільшення експорту товарів забезпечуватиметься збереженням сприятливої кон'юнктури ринку на традиційні товари українського експорту і в першу чергу на товари сільськогосподарського виробництва, що сприятиме закріпленню досягнутих позицій на зовнішніх ринках, а також пошуку нових ринків збуту [8].

На поліпшення конкурентного середовища аграрних підприємств Херсонської області негативно впливають функціонування тіньових фінансових потоків, фіктивне банкрутство підприємств, реалізація сільгоспсировини без глибокої переробки, діяльність у регіоні філій аграрних підприємств з інших областей України, які сплачують податки за межами Херсонщини (за місцем реєстрації головних підприємств).

Великого значення в розвитку стратегії підвищення конкурентоспроможності сільськогосподарських і переробних підприємств має набути реструктуризація економічно слабких суб'єктів господарювання. Метою реструктуризації є системний підхід до економічного оздоровлення підприємств та поліпшення їх адаптації до умов господарювання в ринкових умовах [9]. Потреба у реструктуризації виникає у суб'єктів господарювання як результат утрати конкурентоспроможності внаслідок виробництва ними неякісної і дорогої, неконкурентоспроможної продукції, яка не користується попитом у споживачів. Ціль реструктуризації підприємств - відновлення їхньої конкурентоспроможності в перспективі шляхом здійснення відповідних оперативних i стратегічних заходів.

Стратегія конкурентоспроможності аграрних підприємств у регіоні повинна базуватися на процесах як горизонтальної, так і вертикальної інтеграції підприємств у рамках АПК. Інтегровані об'єднання є системами втілення комбінації виробничих, наукових і комерційних структур, які, використовуючи переваги спільної взаємодії, отримують конкурентні переваги [10].

Як інструмент інтенсифікації розвитку вітчизняного виробництва інтегровані об'єднання сільськогосподарських підприємств із підприємствами інших галузей можуть значно посилити свої конкурентні позиції як на внутрішньому, так і зовнішньому ринку збуту виробленої продукції.

На даному етапі економічного розвитку підприємства в Херсонській області найбільш доцільною формою інтегрованих об'єднань можуть бути кластерні, змішані або ж універсальні.

Кластери - це галузеве або міжгалузеве територіальне добровільне об'єднання наукових та виробничо-комерційних структур [11].

Ядром кластеру є велике підприємство, навколо якого групуються малі та середні підприємства.

Кластер в умовах Херсонщини може стати новим інструментом підвищення конкурентоспроможності регіону та каталізатором розвитку сільськогосподарських, переробних та харчосмакових підприємств, а також основою відродження машинобудування сільськогосподарського спрямування.

В основі розвитку кластеризації лежить поглиблення форм суспільного поділу праці, яке не обмежується мікроекономічними процесами, що відбуваються в кожному окремому підприємстві. Вона являє собою систему різних форм, методів і наслідків суспільної праці, яка складається у результаті якісної диференціації трудової діяльності в процесі розвитку суспільства.

Вступ України до СОТ сприяє підвищенню конкурентоспроможності вітчизняної сільськогосподарської продукції, доступу до ринків ЄС та інших регіонів світу [12].

Разом із цим з'явилася перспектива підвищення якості життя населення, оскільки конкурентоспроможність характеризує ступінь розвитку суспільства. Нерозвинене конкурентне середовище, слабка конкуренція між господарюючими суб' єктами озна- 
чає низьку конкурентоспроможність регіону і його економіки, що негативно позначається на рівні життя населення.

Висновки. Отже, класифікація чинників впливу на формування конкурентних переваг сільгосппідприємств є основою побудови регіональної стратегії управління конкурентоспроможністю аграрних підприємств.

Розробляючи стратегію підвищення конкурентоспроможності сільськогосподарської галузі регіону, необхідно враховувати: можливість створення в регіоні аграрнопереробних об'єднань; підвищення рівня спеціалізації сільськогосподарських підприємств; створення ефективної інформаційної інфраструктури; перспективність розвитку ринкового середовища; перспективу підвищення рівня технічного й інноваційно-технологічного забезпечення сільгосппідприємств; можливість створення привабливих умов для залучення інвестицій та активізації кредитних установ; можливість зміцнення конкурентних позицій на міжрегіональному і міжнародному рівнях; створення умов для реструктуризації економічно слабких суб'єктів господарювання; впровадження служб маркетингу; розроблення і реалізацію в регіоні соціальної програми поліпшення якості життя в регіоні.

\section{Список використаних джерел:}

1. Саблук П.Т., Малік М.Й., Валентинов В.Л. Формування міжгалузевих відносин: проблеми теорій та методології. Київ : IAE, 2002. 294 с.

2. Ковальов В.В. Фінансовий аналіз: Управління капіталом. Вибір інвестицій. Аналіз звітності. Київ : Фінанси та статистика, 1999. 260 с.

3. Амбросов В.Я., Онегіна В.М. Забезпечення державної підтримки сільськогосподарського виробництва в умовах членства України в СОТ. Економіка АПК. 2009. № 2. С.15-17.

4. Амбросов В.Я., Маренич Т.Г. Розвиток земельного ринку та іпотечне кредитування. Економіка АПК. 2009. № 10. С. 104-110.

5. Матеріально-технічне забезпечення сільського господарства України : навчальний посібник / Ю.О. Лупенко та ін. Київ : ННЦІАБ, 2015. 141 с.

6. Кирилов Ю.С., Грановська В.Г. Підвищення конкурентоспроможності аграрних підприємств України на основі впровадження інновацій. Інвестииії: практика та досвід. 2019. № 24. C. 5-9.

7. Чабан В.Г. Інновації як умова підвищення конкурентоспроможності аграрного сектору. Економіка АПК. 2006. № 7. С. 68-72.

8. Боровік Л.В. Аналіз формування та використання інвестиційного потенціалу у сільськогосподарській галузі України. Науковий вісник Херсонського державного університету. Серія «Економічні науки». 2018. Вип. 30-3. С. 92-95.

9. Федоренко В.Т., А.Ф. Гойко, В.Б. Джабейло. Кластери - системний інструмент підвищення конкурентоспроможності економіки. Економіка та держава. 2007. № 9. С. 6-9.

10. Крисальний О.В. Трансформація колективних сільськогосподарських підприємств у кооперативні формування. Економіка АПК. 2000. № 3. С. 12-15.

11. Бородіна О.М., Т.В. Бурлай, Н.І. Горшкова. Конкурентоспроможність економіки України: стан і перспективи підвищення : монографія. Київ : Основа, 2007. 488 с.

12. Портер М.Е. Стратегія конкуренції: Методика аналізу галузей і діяльності конкурентів / пер. $з$ англ. Київ : Основа, 1998. 390 с.

13. Agricultural Outlook 2007-2016. URL: http:www.oecd.org/dataoecd/6/10/ 38893266.pdf.

\section{References:}

1. Sabluk P.T., Malik M.Y., Valentynov V.L. (2002) Formuvannya mizhhaluzevykh vidnosyn: problemy teoriy ta metodolohiyi [Formation of intersectoral relations: problems of theories and methodology]. Kyiv: IAE.

2. Koval'ov V.V. (1999) Finansovyy analiz: Upravlinnya kapitalom. Vybir investytsiy. Analiz zvitnosti [Financial Analysis: Capital Management. Investment choice. Reporting analysis]. Kyiv: Finansy ta statystyka.

3. Ambrosov V.Ya., Onehina V.M. (2009) Zabezpechennya derzhavnoyi pidtrymky sil's'kohospodars'koho vyrobnytstva $\mathrm{v}$ umovakh chlenstva Ukrayiny v SOT [Providing state support for ag- 
ricultural production in the context of Ukraine's membership in the WTO]. Ekonomika APK, no. 2, pp. $15-17$.

4. Ambrosov V.Ya., Marenych T.H. (2009) Rozvytok zemel'noho rynku ta ipotechne kredytuvannya [Land market development and mortgage lending]. Ekonomika APK, no. 10, pp. 104-110.

5. Lupenko Yu.O., Zakharchuk O.V., Vyshnevs'ka O.V. ta in. (2015) Material'no tekhnichne zabezpechennya sil's'koho hospodarstva Ukrayiny [Material and technical support of agriculture of Ukraine]. Kyiv: NNTSIAB.

6. Kyrylov Yu.Ye., Hranovs'ka V.H. (2019) Pidvyshchennya konkurentospromozhnosti ahrarnykh pidpryyemstv Ukrayiny na osnovi vprovadzhennya innovatsiy [Increasing the competitiveness of agricultural enterprises of Ukraine on the basis of innovation]. Investytsiyi: praktyka ta dosvid, no. 24 , pp. 5-9.

7. Chaban V.H. (2006) Innovatsiyi yak umova pidvyshchennya konkurentospromozhnosti ahrarnoho sektoru [Innovation as a condition for increasing the competitiveness of the agricultural sector]. Ekonomika APK, no. 7, pp. 68-72.

8. Borovik L.V. (2018) Analiz formuvannya ta vykorystannya investytsiynoho potentsialu u sil's'kohospodars'kiy haluzi Ukrayiny [Analysis of the formation and use of investmet potential in the agricultural sector of Ukraine]. Naukovyy visnyk Khersons'koho derzhavnoho universytetu. Seriya «Ekonomichni nauky», no. 30-3, pp. 92-95.

9. Fedorenko V.T., Hoyko A.F., Dzhabeylo V.B. (2007) Klastery - systemnyy instrument pidvyshchennya konkurentospromozhnosti ekonomiky [Clusters are a systemic tool for increasing the competitiveness of the economy]. Ekonomika ta derzhava, no. 9, pp. 6-9.

10. Krysal'nyy O.V. (2000) Transformatsiya kolektyvnykh sil's'kohospodars'kykh pidpryyemstv u kooperatyvni formuvannya [Transformation of collective agricultural enterprises into cooperative formations]. Ekonomika APK, no. 3, pp. 12-15.

11. Borodina O.M., T.V. Burlay, N.I. Horshkova (2007) Konkurentospromozhnist' ekonomiky Ukrayiny: stan i perspektyvy pidvyshchennya [Competitiveness of Ukraine's economy: state and prospects of increase] : monohrafiya. Kyiv: Osnova.

12. Porter M.E. (1998) Stratehiya konkurentsiyi: Metodyka analizu haluzey i diyal'nosti konkurentiv [Competition strategy: Methods of analysis of industries and activities of competitors]. Kyiv: Osnova.

13. Agricultural Outlook 2007-2016. Available at: http:www.oecd.org/dataoecd/6/10/38893266.pdf. 